ENTREVISTA

\title{
UM REALISMO MINIMALISTA
}

João de Pina Cabral

Já há alguns anos, João de Pina Cabral mantém uma relação estreita com a antropologia brasileira. Visita regularmente o país, participa de seminários, oferece cursos e cultiva uma intensa troca intelectual com os colegas. Recentemente, abriu uma frente de pesquisa etnográfica no sul da Bahia, voltando sua reflexão para - Brasil. Sua rara trajetória antropológica passa pela Europa, África, Ásia e, agora, América Latina, atravessando temáticas de pesquisa igualmente diversas: a vida dos camponeses portugueses, a dinâmica das identidades em Macau e em Moçambique, os afetos, os nomes e as concepções da pessoa no Brasil. Soma-se a isto uma arguta reflexão sobre o presente e o futuro da antropologia, resultado não apenas da experiência de ensino e pesquisa em diversos continentes, mas também da ativa participação na institucionalização da disciplina. Pina Cabral é um dos fundadores dos departamentos de antropologia do ISCTE e da Universidade de Coimbra, da Associação Portuguesa de Antropologia e da Associação Europeia de Antropologia (EASA), das quais foi também presidente. Atualmente, é pesquisador-sênior do Instituto de Ciências Sociais de Lisboa. Tendo como fio condutor elementos de sua trajetória pessoal, Pina Cabral oferece nesta conversa com Carlos Fausto e Federico Neiburg, ocorrida no Rio de Janeiro em 25 de junho de 2007, um panorama agudo sobre os debates contemporâneos da antropologia, manifestando a visão de um antropólogo singularmente cosmopolita. 
FN: Sua trajetória é bastante particular. Você nasceu em Portugal, formou-se entre Moçambique e África do Sul, depois em Oxford. Fez pesquisas em Portugal, Macau e no Brasil. Conte-nos um pouco essa história e como a antropologia entrou em sua vida.

Quando cheguei à antropologia eu estava numa situação de marginalidade entre dois tempos: o tempo do colonialismo e da missionação e o tempo do socialismo e da independência. Encontrei-me em Moçambique, como filho de um missionário, a observar a guerra pela independência e, em Joanesburgo, durante os anos de levantamento popular contra o apartheid. Estava a ocorrer uma mudança no mundo à minha volta, uma mudança política, mas sobretudo uma mudança de paradigmas. A minha chegada à antropologia prende-se a isto tudo: o problema inicial foi o da cristianização da África, que se revelava aos meus olhos de adolescente como profundamente dilemática. Quando cheguei a Joanesburgo, descobri a antropologia largamente por acaso. Mas os meus professores tinham percursos muito parecidos com o meu. O Hammond-Tooke, meu primeiro orientador, era filho de um ilustre missionárioetnógrafo. Estávamos a assistir a uma profunda crise ideológica no pós-Maio 1968. A antropologia também estava em revolução interna com a chegada do estruturalismo e do marxismo estrutural.

\section{CF: Em que universidade de Joanesburgo você estudou?}

Witwatersrand, que era a maior universidade de língua inglesa no país. Ali, o polo teórico dominante na antropologia era um estruturalismo marxista ligado ao movimento revolucionário interno à própria África do Sul.
CF: Você vinha, então, de Moçambique? Eu fui para Moçambique com 13 anos nós pertencemos a uma antiga família protestante do norte de Portugal. O meu pai foi nomeado bispo anglicano de Moçambique (Bispo dos Libombos, é o título). Foi o último bispo missionário anglicano. Aliás, ele foi escolhido já em função da mudança que estava a ocorrer dentro do anglicanismo na África do Sul, personificada por figuras como o bispo Tutu, que ainda hoje é amigo do meu pai. Mas essa história é mais antiga, ela passa pelo bispo Zulu e pelo Arcebispo SelbyTaylor, que foram os que prepararam a mudança no anglicanismo sul-africano, que depois teria um papel tão importante no fim do apartheid. A presença do meu pai em Moçambique, portanto, liga-se à tentativa de "localizar" o anglicanismo. Eles escolheram-no porque supuseram que, como português, poderia comunicar-se melhor com a administração colonial e facilitar o processo de transição para um bispo africano - como de fato ocorreu.

CF: E por que foi de Moçambique para a África do Sul?

A tradição familiar era estudar direito, mas eu recusei-me a fazer isso. Fui para a África do Sul porque tinha vagamente a ideia de que queria estudar "a mente humana"... achava que queria ser psicólogo! Depois descobri a antropologia e nunca mais olhei para trás! Cheguei à África do Sul em 1972 e fiquei lá até 1977, mas na verdade a África do Sul foi sempre um local de passagem para mim. $\mathrm{Na}$ época, Joanesburgo ainda tinha um ótimo departamento de antropologia. Só que, depois, confrontado com a independência de Moçambique, o meu projeto de ser um antropólogo africanista - era para isto que eu estava a preparar-me - 
capotou. Em 1977 percebi que não tinha condições para ficar na África Austral, porque não tinha visto de residência na África do Sul e, em Moçambique, como filho de um missionário, não havia lugar para mim. Em boa verdade, em 77 começávamos já a ver que o projeto de independência de Moçambique talvez não fosse o que tínhamos sonhado. Então, tive de refazer o meu projeto de vida e voltar à Europa.

\section{CF: Portugal não era um pouco estranho} para você? Você desde os 13 anos estava na África Austral...

Claro, Portugal era estranho para mim, embora eu tivesse sido criado como português. De fato, as nossas referências literárias eram portuguesas, mas sobretudo francófonas. Quando cheguei à África do Sul eu lia francês fluentemente (na altura estava a devorar o Proust com enorme entusiasmo), mas não lia inglês. Tive que aprender inglês na Universidade. Essa marca de certa cultura "continental", como dizem os ingleses, sempre foi uma coisa forte em mim. Cheguei mesmo a pensar em ir estudar na França, mas por fim escolhi a Inglaterra. Passei o inverno de 1974 para 1975 em Paris. Assisti mesmo ao seminário do Lévi-Strauss sobre a identidade. Foi sem planejamento. Queria saber quem era o Lévi-Strauss; fui ao Collège de France; vi uns painéis impressos indicando um seminário: "Prof. Claude Lévi-Strauss Séminaire sur l'identité". Decidi ir. Lembro-me que entrei, sentei-me, e só no fim do seminário percebi que o senhor ao meu lado era o Maurice Godelier. Quase perdi a respiração - os professores mais jovens em Joanesburgo achavam que ele era o suprassumo. Estavam lá também a Françoise Zonabend, a Martine Segalen e outras pessoas das quais depois me tornei amigo, mas só muitos anos depois. Afinal, foi essa experiência que me fez decidir a não ir fazer antropologia na França. Porque apesar de eu ser, ainda hoje, um fã do Lévi-Strauss, a verdade é que senti que na França, àquela altura, não havia um projeto antropológico consistente. Ora, na época, eu estava muito influenciado pela leitura da obra etnográfica do Maurice Bloch.

\section{FN: Você já o conhecia pessoalmente?}

Não, de maneira nenhuma. Mas fui para a Inglaterra porque queria estudar com ele na London School of Economics. Só que ele estava de sabático nos Estados Unidos nesse ano. Quando soube fiquei muito triste. Estava no Porto. Então, telefonei para Londres, para a UCL [University College of London], para ver se havia alguém que me sugerisse o que fazer. Alguém respondeu ao telefone e disse-me com muita segurança que fosse para Oxford, onde havia um senhor que iria me orientar muito bem, o John Campbell. Quem fez a indicação, descobri mais tarde, foi o Michael Gilsenan, que era o responsável pelos graduate studies na UCL nesse ano.

FN: Mas por que razão ele mandou você estudar com John Campbell? Você já tinha algum projeto? Você queria estudar Portugal? Por isso foi encaixado na Antropologia Mediterrânea?

Isso mesmo. Eu já tinha feito a minha tese de B.A. Honours (uma espécie de mestrado na África do Sul) sobre um conto popular português. ${ }^{1}$ Era uma leitura profundamente influenciada pelo Pierre Maranda. Fazia, portanto, algum sentido estudar com um especialista sobre sociedades rurais europeias, já que era o terreno que eu iria abordar. 
Então, em 1977, fui para Oxford para fazer trabalho de campo no Alto Minho (norte de Portugal). Em Oxford, caí no meio desse caldo pós-estruturalista. Lembro-me (esta história tem alguma graça porque mostra a atmosfera da época) que a primeira pessoa que eu quis conhecer em Oxford foi o Rodney Needham. Era a figura dominante do estruturalismo inglês. Era uma pessoa extraordinária, um homem intelectualmente poderosíssimo, mas muito desiludido com o mundo e com a vida. Era um sistêmico que levava todas as suas ideias até as últimas consequências. Nunca se deve fazer isso! No momento em que um estruturalista como ele prova que o conceito de contradição não é consistente em termos lógicos, ${ }^{2}$ realmente ocorre uma espécie de curtocircuito intelectual. Mas era uma figura com uma enorme profundidade analítica, um sentido de procura e de honestidade intelectual extraordinário.

FN: Quando você chegou a Oxford já estava definido que estudaria com Campbell?

Sim, foi ele quem me aceitou para a pós-graduação no Instituto, mas acontece que ele e Needham eram grandes amigos. Quando visitei este último, ele perguntou-me o que eu queria fazer, e eu respondi que queria fazer uma análise estruturalista da religião em Portugal. Então, ele sugeriu que, antes de tudo o mais, eu deveria ler um livro chamado La langue verte et la cuite ${ }^{3}$ - era essencial que eu lesse este livro. Fui à biblioteca central (a imponente Bodleyan Library), inscrevi-me como leitor e peguei logo o livro que ele me recomendara. Foi o primeiro livro que li em Oxford - mas, afinal, era uma practical joke, uma elaborada piada à custa do Lévi-Strauss e de mim. O Needham estava, assim, a passar-me uma mensagem, como que a dizer: "Olha, isso tudo neste momento está a colapsar esta gente anda a levar-se demasiado a sério". Era basicamente isso.

CF: Mas no contexto da África do Sul dominado pelo marxismo estrutural, Lévi-Strauss não era também uma figura central na época?

No departamento havia três correntes. Havia a mais radical, marxista, que lia Claude Meillasoux, Pierre Philippe Rey e Maurice Godelier e que acabou opondo-se à própria antropologia, num movimento antiacademicista de imersão no ativismo político. A figura máxima dessa corrente foi o David Webster, cuja brilhante tese sobre parentesco em Moçambique estamos agora a publicar postumamente no ICS e que foi assassinado pelo regime em 1989. ${ }^{4}$ Havia uma segunda corrente mais literária de estruturalismo lévistraussiano, da qual eu me aproximava mais. E depois havia uma terceira linha ligada à Escola de Frankfurt, que lia o primeiro Habermas do Conhecimento e Interesse ${ }^{5}$ como quem lê a Bíblia. O paradigma antropológico clássico tinha colapsado. Estas três correntes teóricas apareciam como tentativas de saída da crise e partiam todas da convicção de que aquilo que havia sido a grande tradição anglófona da antropologia sul-africana tinha terminado. O último livro do Hammond-Tooke - Imperfect Interpreters ${ }^{6}$ - é quase comovente nessa medida. É o livro de alguém que faz o luto do seu passado intelectual: uma grande escola antropológica fundada por Radcliffe-Brown em 1921, com um incrível impacto em nível global, mas que após 1970 tinha entrado em colapso terminal. O boicote acadêmico promovido pelo ANC teve o efeito trágico de isolar os acadêmicos anglófanos anti-segregacionistas, abafando as vozes de dissensão na África do Sul. As figuras que poderiam ter sido os gran- 
des antropólogos sul-africanos dessa geração-Adam Kuper e os Comaroff - foram obrigados a ir embora, desapareceram. Esta sensação de vácuo, sem novas saídas à vista, estava muito viva à altura em que eu próprio decidi sair da África em 1977, logo após os levantamentos de Soweto.

CF: Então quando você sai da África do Sul, o estruturalismo era, digamos, a vanguarda de uma tentativa de superação. Quando você chega em Oxford, ele já estava sendo objeto de crítica...

Isso mesmo! Foi uma coisa problemática para mim. Ainda por cima, nos finais dos anos 70, a Antropologia do Mediterrâneo estava a entrar também num processo de requestionamento.

\section{FN: Como assim?}

Na verdade, o mediterranismo inglês tem sido muito mal entendido, porque é de raiz simmeliana. Só que isto não fica claro na Inglaterra. As primeiras traduções do Simmel para o inglês surgem nos anos 50, na altura em que o mediterranismo está também a aparecer em Oxford. Ora, os professores aí, Radcliffe-Brown e EvansPritchard, concebiam-se como discípulos da Année Sociologique. Pelo contrário, o responsável por divulgar o Simmel em Oxford foi o Franz Baerman Steiner, ${ }^{7}$ que teve um papel importantíssimo como orientador do Pitt-Rivers e foi inspirador dos Bohannan, da Mary Douglas e do Srinivas, mas que morreu muito cedo, em 1952. O Evans-Pritchard, na sua política perversa referente a citações acadêmicas, desencorajava as pessoas de citarem tudo o que fossem referências teóricas. É o próprio Pitt-Rivers quem conta isto no segundo prefácio ao People of the Sierra. ${ }^{8}$ Eu dou muita importância a esta questão, porque creio que o primeiro mediterranismo, em Oxford, tem sido mal entendido. Ele cor- responde a uma antropologia sociológica preocupada com a pessoa, os valores, as emoções e as interações. O conceito de honra e vergonha do Pitt-Rivers e do Campbell deve ser lido à luz de Simmel, não como uma qualquer noção de cultural trait - como depois foi interpretado pela antropologia cultural americana de tradição boasiana difusionista. ${ }^{9}$

FN: Vale a pena um parêntese, pois nós aqui, no Brasil, lemos a antropologia do Mediterrâneo há muito tempo nessa chave simmeliana. É notável que no Brasil tenhamos apreciado a forma original, não segundo o cânone americano. E isto tem a ver com a maneira pela qual se constitui a antropologia no Brasil, apreciando a primeira tradição sociológica alemã.

CF: Aqui não houve o silenciamento. A pergunta seria, então, por que na Inglaterra se silenciou uma referência teórica importante...

Aí vocês têm duas questões. No Brasil, isto talvez se deva à passagem de Gilberto Velho por Chicago e à sua amizade com Howard S. Becker. Mas, acreditem, lá na Inglaterra, o paradigma clássico durkheimiano continua a constituir a história oficial do período clássico. Em Oxford, tal era definidor de uma identidade teórica antropológica. Além disso, há aí uma ambiguidade fundacional no próprio Evans-Pritchard em relação ao projeto mediterranista. Evans-Pritchard nunca conseguiu deixar de desprezar os colegas que estudavam o Mediterrâneo. Este é um fato público. Ele dizia que era uma etnografia fácil. Na verdade, a frase que ele utilizava é que era uma antropologia de senhoras.

FN: O que você acha que estava em jogo nessa luta por definir o que seria a "verdadeira" antropologia? 
Para mim, esta foi uma questão muito importante pela perplexidade que me causou, o que hoje chamo "primitivismo metodológico". Quando comecei a intervir no debate, de repente descobri que eu era visto como um anthropologist at home. Eu era tido como um nativo que estava a fazer "autoantropologia", como agora dizem. Ora, para mim, tudo isso era (e é) completamente aberrante, como podem imaginar. Eu, a essa altura, vinha da África do Sul e Moçambique e voltava a um Portugal camponês com o qual, na verdade, a minha identificação era meramente histórica. Certo, havia um cânon literário português que eu dominava desde jovem e que nunca tinha abandonado, mas isto fazia a minha etnografia anthropology at home? Filhos de Adão, Filhas de $E v a^{10}$ é uma monografia europeísta escrita por um africanista era o meu background intelectual à época. Só posteriormente vim a conhecer melhor o mediterranismo, levado até pela necessidade de compreender o que se estava a passar à minha volta. Os meus referentes intelectuais eram africanistas e foi este, acho eu hoje, um dos principais interesses do que acabei por escrever. Isto está na base também da minha inconformidade com o nacionalismo reflexo que está implícito em tantos projetos de investigação antropológica: se você estuda a Grécia, você é um especialista sobre a Grécia, mesmo que esteja a estudar albaneses na fronteira com a Albânia. Isto faz sentido? Se você é um americano que estuda a Espanha, você tem a obrigação de citar tudo o que se escreveu em inglês sobre a antropologia de Espanha, mas não precisa conhecer o que se passa a $5 \mathrm{~km}$ do outro lado da fronteira, em Portugal ou na França. Então, esse nacionalismo inscrito nas agendas antropológicas foi realmente uma das minhas principais fontes de perplexidade comparativa.
FN: Eu acho que essa crítica ao nacionalismo inscrito nas agendas de pesquisa se relaciona também com a necessidade, por parte da antropologia do Mediterrâneo, de lidar com as tradiçóes do folclore europeu. Isto, a meu ver, paradoxalmente, é também uma fonte da sofisticação e da riqueza da antropologia do Mediterrâneo, o fato de ter que lidar explicitamente com essas "antropologias" que são ou que pretendiam ser também ideologias nacionais.

É verdade. Num certo sentido, toda a antropologia que é feita sobre a Europa assenta sobre o passado da etnologia nacional. Eu nunca recusei isto, muito ao contrário. Não só não recusei como foi um caminho que explicitamente quis trilhar, pois havia uma riqueza no que isto permitia de constituição de temporalidades. Permitia-me compreender historicamente muitas das coisas que eu estava a observar. Vou dar-lhes uma ideia: quando estudava no Minho as relações de gênero e os rituais ligados à domesticidade, recorria a um modelo interpretativo que faltava ao Leite Vasconcellos nas décadas de 1910 e 20. Mas o material que ele nos tinha deixado sobre os costumes ligados à vida doméstica abria-se a reinterpretações baseadas num novo enquadramento teórico. Isto foi algo que percebi logo, no início desse primeiro projeto sobre um conto popular português, justamente editado por Leite Vasconcellos. O que nós precisávamos era de uma releitura socioantropológica, moderna, do material da etnologia. Nos anos 80, em Portugal, esta era uma das nossas tarefas principais.

FN: Creio que há aí uma dupla questão: essa produção é uma fonte inestimável de riqueza, que possibilita inclusive trabalhos como o seu, mas ela obriga, ao mesmo tempo, a cultivar um espírito 
crítico em relação à antropologia em geral. Penso no seu trabalho e naquele de Michael Herzfeld, por exemplo. ${ }^{11}$ Parece que, nesse plano, os dois se aproximam bastante.

O Herzfeld também foi aluno de John Campbell, mas ele é uns anos mais velho do que eu, pertence à geração anterior. A visão dele é mais marcada pelo culturalismo americano e, ao mesmo tempo, por um fascínio mais inocente pelo pós-modernismo. A minha geração é mais sóbria. De fato, fomos uma geração sacrificada. Muitos de nós acabaram por não conseguir fazer carreira acadêmica porque, não se esqueçam, nos anos 80, Mrs. Thatcher fez um ataque brutal à antropologia. Durante praticamente dez anos não houve novos empregos no ensino ou na investigação na Inglaterra. Os que sobreviveram foram para fora. Eu tive muita sorte, porque as Ciências Sociais em Portugal estavam a ser refundadas. Era o vácuo absoluto, foi preciso lançar tudo de novo. Realmente, acho que tive imensa sorte, porque as universidades portuguesas estavam a renascer.

CF: Isso não começa já após o 25 de abril de 1974 ?

Não é bem pós-25 de abril, não. É após a reconstituição das universidades, no início dos anos 80. É por essa altura que a coisa começa a se consolidar, que começam a surgir novos departamentos, a carreira acadêmica começa a funcionar a sério em moldes modernos, as pessoas começam a fazer doutoramentos outra vez. Na antropologia havia duas tradições que tivemos de defrontar. Por um lado, a antropologia colonial que tinha estado fortemente engajada na luta contra as guerrilhas africanas e tinha concebido o lusotropicalismo dos anos 60. Por outro lado, o velho projeto etno- lógico. Ora, se calhar até por causa da minha história pessoal, eu sempre vi esta última com algum carinho. Eu sempre respeitei a scholarship deles, a preocupação em produzir conhecimento sistemático, ao contrário da antropologia colonial, que tinha um componente ideológico e político muito vincado. Ambos os projetos eram nacionalistas e ambos tinham sobrevivido devido à ditadura, mas eram diferentes.

\section{CF: A ditadura em Portugal afetou de alguma forma a sua formação?}

Claro que sim! Nós, na África, fazíamos parte do mundo português. O meu pai dialogava com esta questão diariamente. Ele fez até um ano de prisão nos anos 40 por ser protestante. Era um regime muito brutal e opressivo. O colonialismo português não era só colonialismo, era também fascismo, portanto, virava-se também contra os portugueses. A atmosfera que nos rodeava de tacanhez intelectual, de opressão religiosa, de obscurantismo era muito forte, tanto em Portugal como em Moçambique. Talvez em Moçambique um pouco menos, porque contrariamente a Angola, Moçambique vivia certo estado de relativa calma, porque estava longe demais para criar problemas à ditadura em Portugal. Então, permitiam-se ali alguns laivos de liberalismo. Eu, por exemplo, tive um professor de história que foi muito importante para mim, e que tinha sido secretário geral do Partido Comunista (Cansado Gonçalves). Só lhe foi permitido entrar em Moçambique, mas não em Portugal ou em Angola.

CF: E quando você volta para Portugal, com esse espírito intelectual fundacional, qual era a ideia que vocês traziam do que deveria ser a antropologia naquele momento? Qual era o lugar da antropologia naquele contexto? 
O problema com a pergunta é o plural. É que nós não éramos um sujeito coletivo. De maneira nenhuma. Cada um vinha do seu canto. Uns vinham de Genebra, outros vinham de Louvaine, de Paris, da Inglaterra, dos EUA. Cada um vinha com a sua história diferente para contar e este foi realmente o grande fator de dificuldade nos anos 80: diferentes perspectivas, diferentes visões, diferentes projetos, como conjugar essa diversidade? E ainda tínhamos, é claro, a sobrevivência de uma intelligentsia ligada ao Antigo Regime que, na época, tentava se reimpor (e, até certo ponto, com algum sucesso, como se pode ver hoje). Os anos 80 em Portugal foram de grande conflitualidade intelectual; de dúvida, mas ao mesmo tempo de produtividade. Estávamos a formar alunos em novos moldes, a fundar cursos novos; refundamos a Associação Portuguesa de Antropologia... havia espaço para fazer coisas novas.

CF: Este é o momento também em que começam a surgir os trabalhos da Marilyn Strathern que, no final dos anos 80, viriam a ter um impacto muito grande sobre a antropologia britânica, criando uma nova espécie de antropologia britânica, nãoamericana, apesar de toda a influência de Roy Wagner e David Schneider.

Eu, pessoalmente, senti logo o impacto dessas mudanças no princípio dos anos 80. Aqueles primeiros textos que a Marilyn escreveu sobre a pessoa em Mount Hagen foram até mais influentes para mim do que os textos posteriores. ${ }^{12}$ Foi o impacto da antropologia feminista que obrigou a um repensar do conceito de pessoa. Para mim isto foi muito marcante no período em que preparava a tese para publicação (1982-1986). Mas, de fato, o impacto dos trabalhos de Strathern foi mais sentido no fim dos anos 80, princípio dos anos 90, com Gender of the gift ${ }^{13} \mathrm{e}$, depois, com aquele livro editado pelo Tim Ingold, Key debates in anthropology, que realmente constituiu o marco teórico de consagração, no qual a Marilyn é a figura de proa. ${ }^{14}$

FN: Como você vê a relação entre a emergência de Marilyn Strathern como uma figura de referência no contexto das elaborações teóricas e das relações tensas entre as antropologias britânica e americana nesse momento? Trata-se de uma relação ambígua, não é?

A questão é absolutamente esta. A Marilyn nunca assumiu uma posição de confronto com a antropologia americana. Pelo contrário. E quando ela escreve After Nature, em certo sentido até anda para trás. ${ }^{15}$ After Nature é um livro, como ela diz, cuja paternidade é de David Schneider, e eu creio que esse namoro com o culturalismo schneideriano, na segunda metade dos anos 90, desviou-a do projeto de repensar uma antropologia social.

CF: Mas é curioso, porque na verdade tanto Schneider como Wagner, que vão ser as grandes influências da Marilyn Strathern, não são os autores triunfantes na nova antropologia americana, que vem muito mais, digamos, dessa vertente literária a partir do Geertz e dos seus críticos.

Schneider é colega de Geertz e co-discípulo de Parsons. Os dois vieram de Harvard. Isto é muito importante para compreender, por exemplo, até o que a Sherry Ortner está a escrever hoje. Essa marca do parsonianismo está lá. Apresenta-se como uma antropologia da cultura e parece assentar sobre uma teorização do conceito de cultura. Mas cultura é uma coisa que é tida por grupos, e "grupo" é categoria não teorizada por eles que remete para uma lógica parsoniana. Esta é a minha leitura e 
ela aplica-se tanto a Schneider como a Geertz. Refiro-me a Schneider especialmente só por causa do impacto que ele teve na Marilyn dos anos 90 e que, para mim, levou a Marilyn por um caminho menos interessante que o inicial.

CF: E é nesse período, início dos anos 90, que você começa a pesquisa em Macau?

Precisamente. Nessa altura comecei a achar que não fazia sentido continuar a trabalhar com camponeses em Portugal, porque já não havia camponeses. Para fazer a coisa honesta, eu teria que refazer tudo de novo. Teria que fechar portas, arquivar o material antigo e voltar ao princípio: fazer outra vez a etnografia de umas pessoas que eram agora constituídas por diferenças que já não eram as mesmas da geração anterior com a qual eu tinha trabalhado. A entrada na sociedade de consumo alterara os parâmetros da estruturação social e cultural da sociedade rural portuguesa. Foi tudo muito rápido. É uma revolução social que ocorre a partir de 69, que tem seu pico em 76-77 e que, em 86, está definitivamente terminada. E então, nessa altura, eu fui desafiado a ir para Macau. A princípio, disse que não, mas realmente a oferta era tão atraente que acabei por ir.

CF: Mas qual era a questão que o motivava?

Eu tinha um problema que me preocupava: é que nunca tinha feito etnografia num contexto social em que o fator etnicidade fosse importante, e isso para mim era um problema. Eu estava a ver isso a chegar em Portugal. Via bem que a etnicidade seria um grande tema nos anos 90 e queria perceber como é que eu abordaria a questão. Macau era o terreno perfeito para analisar o conceito, porque era uma margem... Era a maneira de realmente testar tudo o que naquele momento eram hipóteses. Era quase um laboratório de questões relativas à etnicidade e isto me fascinou muito.

CF: Macau, do ponto de vista da descolonização, tem uma história complexa, é como se você tivesse camadas de processos diversos, que você traduziu como etnicidade. É diferente da colonização africana que você conhecia tão bem, inclusive por experiência pessoal. Como você compara essas duas experiências, africana e macaense?

De fato, trata-se de processos de descolonização muito diferentes, o que pode ser enxergado de forma muito clara através da questão da etnicidade. Em Macau encontrei uma constituição étnica totalmente diferente da africana. Na África, havia um binarismo hierárquico absoluto: os colonizadores - brancos, ricos, modernos e com conhecimento poderoso (a questão do saber/poder é muito importante) - e os colonizados - negros, pobres, tradicionais, rurais, "ignorantes". Em Macau e Hong Kong não se passa assim, existe um sistema que cruza etnicidade com classe, de tal maneira que você tem uma classe alta chinesa de cariz comercial, uma classe média administrativa portuguesa ou mestiça e uma classe baixa chinesa. Então, a dinâmica do estigma étnico (por isso o subtítulo do meu primeiro livro é Dinâmicas da Etnicidade Macaense ${ }^{16}$ ) é dupla, não tem o sentido único que tinha em África. Hoje, a África é muito diferente, mas na China sempre houve uma poderosa elite autóctone e um imaginário que atribui o poder cultural, a sofisticação maior à China; que posiciona os chineses como superiores perante os outros povos. Então, nesse aspecto, a minha anterior experiência africana constituiu um contraste em Macau. 
FN: Isto coincidiu também com a criação da EASA (European Association of Social Anthropology).

Coincidiu absolutamente. São processos paralelos. No meu caso pessoal, o desafio foi lançado pelo Adam Kuper. Eu não o conhecia pessoalmente, mas ele era então editor da Current Anthropology. Quando eu escrevi aquele texto crítico sobre o Mediterrâneo, Adam apoiou-me contra muitos que teriam preferido evitar o debate, o que nos aproximou.$^{17}$ Ele contactou-me, o que me agradou muito, porque eu o respeitava, por causa do meu background africanista e pelo meu gosto pela história da antropologia. Foi muito interessante trabalhar com ele na fundação da EASA.

\section{FN: Qual era a motivação de vocês?}

O contexto dizia respeito ao papel da antropologia num mundo após a Guerra Fria. Porque, com a queda do Muro de Berlim, estavam a acontecer coisas inesperadas: por um lado, na Europa, o Leste juntava-se a nós, como se cumprisse um destino. Este era o móbil principal do Adam e do Ernst Gellner. Mas também tinha havido, dois anos antes, a negociação sobre Hong Kong e Macau e, logo depois, o fim da Guerra Civil em Moçambique e o princípio do fim da Guerra Civil em Angola. O mundo estava a reestruturar-se. Nós estávamos a ver estas mudanças a ocorrer vertiginosamente. Elas tinham implicações na própria maneira de fazer antropologia, porque nós, como antropólogos, fazemos parte desses processos, tanto numa aproximação ao Leste, como na maneira como nós víamos o nosso próprio objeto num contexto pós-colonial: a entrada de Portugal na União Europeia, o fim do último colonialismo português em Macau e, em certo sentido, o fim definitivo do colonialismo em África, com o termo das guerras civis. As lógicas sociais do colonialismo português não acabaram logo com a independência; só acabada a guerra civil subsequente é que começa a ser possível antever novas tramas sociais africanas. Até lá as guerras criaram um hiato que prolongava o período anterior, não permitindo construir nada de genuinamente novo.

FN: Eu creio que nesse percurso se pode identificar também a cultivação de um tipo de antropologia crítica, consciente da necessidade de criar as condições institucionais para que ela se desenvolva. Um pouco como acontece no Brasil. Podemos dizer isto agora tranquilamente, quando o PPGAS faz 40 anos e a antropologia moderna no Brasil tem já algumas gerações. Nesse sentido, a nossa geração tem uma casa feita, diferente de quando você chegou a Portugal. Ainda assim, a sensação que temos no Brasil é a de que há um espaço aberto, um campo de possibilidades muito rico que obriga ao mesmo tempo a produzir etnografia, discutir teoria e trabalhar o tempo todo sobre as condições materiais e institucionais de possibilidade disso tudo. Se a gente olha para os Estados Unidos, não se encontra mais esse perfil de pessoas...

De fato, houve nos Estados Unidos, no tempo da Ruth Benedict, no período pós-Guerra. Mas foi isto de fato que me fascinou enormemente quando descobri a antropologia brasileira, porque eu descobri a antropologia brasileira muito tardiamente, só na segunda metade dos anos 90. Mea culpa.

\section{CF: Tá perdoado, João.}

E ao descobri-la fascinou-me, porque encontrei aqui ecos de uma forma de fazer antropologia que retirava a disciplina 
dessa condição de ciência dos hegemônicos sobre o mundo dos outros. Eu sempre tive muita dificuldade com essa ideia da antropologia como a Ciência do Outro, porque sempre me senti "outro". Esta foi uma questão que me causou sempre dificuldades e que está na base da minha crítica ao mediterranismo. Quando chego ao Brasil e encontro este cruzamento entre uma tradição francesa e uma tradição anglófona, esta constituição de instituições de pós-graduação sólidas, uma antropologia que se concebe a si mesma como autônoma - tudo isto me fascinou muito. Queria poder dizer: eu, por virtude de ser português, não tenho que me vestir de ocidental para fazer antropologia! A herança antropológica é tão minha como de qualquer inglês, francês ou americano, apesar da minha menor "ocidentalidade". O meu fascínio com a antropologia brasileira passa por aí.

CF: Eu vou fazer o papel de advogado do diabo, porque em nossa conversa apareceu uma oposição entre a antropologia americana e as outras antropologias. Talvez não seja exatamente assim, mas me parece que um dos projetos da EASA era criar um bloco que fizesse, digamos, frente a certa hegemonia americana. Não era isto?

Eu acho que não era assim. Isto é uma coisa mal entendida. Adam Kuper tinha uma relação muito forte com setores importantes da antropologia americana e a EASA foi fundada com apoio direto de Eric Wolf e Sydel Silverman, que participaram diretamente das discussões desde o início. O grande desafio era captar as antropologias que já estavam a dar cartas a Oeste (Grécia, Espanha e Portugal) e as novas a Leste - nos antigos espaços das ditaduras do pós-Guerra. Era dizer assim (como disse o Gellner na aula inaugural que fez em 1990 em Coimbra):
"É do Leste que viemos com Malinowski. As nossas raízes também estão aí. Nós não podemos deixá-los sós. Essa gente tem que se juntar a nós porque são nossos". Essa relação com a Europa do Leste, essa necessidade de dizer "vamos trazê-los" foi muito importante. A ideia é claramente esta até o Congresso de Praga, em 1992. As coisas começaram então a mudar, porque perdemos um pouco da nossa inocência com toda essa dinâmica dos Bálcãs. Mas a sensação de que a antropologia americana se põe à nossa frente como um problema só surge mais tarde, no fim dos anos 90. É aí que começamos a sentir o efeito do mecanismo silenciador lançado pelas novas formulações hegemônicas sobre a história da nossa disciplina - gente como Stocking e Clifford, que conta a história da antropologia europeia a partir de uma perspectiva americana.

FN: Bem, mas desde o início tratavase de uma associação de antropologia social...

Naquela altura havia sim o projeto de uma antropologia social, mas isto não era necessariamente visto como antiamericano, até porque pessoas como a Silverman, o Wolf ou o Mintz não se concebiam como antropólogos culturais - os discípulos do Julian Stewart em Nova York sempre se chamaram antropólogos sociais. Foi preciso tomar uma posição defensiva, mas para quem como eu lá esteve, a questão colocava-se institucionalmente. A EASA tinha que evitar o beco do europeísmo. Nós não queríamos nos tornar um subcapítulo da AAA (American Anthropological Association), um ramo da Society for the Anthropology of Europe. Queríamos reivindicar uma antropologia em tempo inteiro, e para isso era necessário certo afastamento da América, porque os americanos só estavam interessados 
em nós como antropólogos da Europa e não na nossa antropologia em geral - que achavam que era uma coisa do passado. Ora, nós queríamos poder fazer antropologia de qualquer parte do mundo, não estávamos interessados em reconstruir o projeto etnológico nacionalista para a nova Europa. Dizíamos: “Não, nós não vamos nos tornar numa associação de antropólogos sobre a Europa; queremos ser antropólogos tão universalistas como quaisquer outros". Foi uma guerra que fizemos nos anos 90 integrando figuras muito importantes da antropologia da época, como John Davis, Ulf Hannerz ou Marilyn Strathern. A última coisa que se pode dizer destes aí é que são antiamericanos. Não são, ou pelo menos não eram nos anos 90. Eu creio que o que estava em causa era a manipulação do nosso passado disciplinar que estava a se realizar nos Estados Unidos. Havia mesmo quem tivesse querido importar o modelo dos 4-fields, sem pensar como este modelo só faz sentido na América do Norte e que, à luz da história acadêmica europeia, se trata de um absurdo tentar exportá-lo para a Europa.

CF: Se o projeto da EASA foi o de incorporar a Europa Oriental, o que foi feito desde então? O que é hoje a antropologia no Leste? Existe uma antropologia da Europa Oriental?

Existe e está francamente a dar provas da sua vivacidade. Existem alguns departamentos bem interessantes. A Polônia e a Eslovênia estão a dar cartas, mas existem departamentos de antropologia bons na República Checa, na Hungria, na Estônia, na Eslováquia. É um bocado difícil prever qual será o resultado teórico de tudo isso, porque, por um lado, a Europa Oriental ainda vive muito o sonho americano e o brain drain americano funciona muito ativamente; por outro lado, porque existem antigas e fortíssimas tradições intelectuais autóctones nesses países, pessoas que são filhos de filhos de filhos de acadêmicos. Essa sensação de uma espécie de sedimentação do conhecimento desde o berço é muito marcada nesses países. Ora, essa tradição prende-se ao papel que as intelligentsias tinham no Império Austro-Húngaro. Era com essa tradição que pessoas como o Gellner sentiam que tínhamos que reatar.

\section{CF: Quais as implicações teóricas disto?}

Creio que ainda é cedo para dizer, mas parece-me que essa reestruturação vai alterar a relevância do eixo anglo-francês. Haverá um reenquadramento das forças teóricas. Por outro lado, é interessante verificar que sobretudo as antropologias inglesa e francesa deixaram marcas por toda a Europa pós-soviética e pós-fascista em Portugal, Espanha, Grécia, Itália, assim como nos países do bloco soviético e na Escandinávia. Muitos dos que hoje lideram os novos departamentos da Europa continental tiveram uma relação constituinte com o eixo anglo-francês. Há certo consenso pela Europa a fora em torno da tradição da antropologia social. Ao mesmo tempo, o impacto da teoria sociológica alemã da Belle Époque não se esgotou. Observam-se laivos de um culturalismo de raiz alemã e nacionalista que encontra ecos no culturalismo americano contemporâneo. A etnologia europeia (folklore, volkskunde), contrariamente ao que a minha geração chegou a pensar, não desapareceu e está a reemergir associada às modas da museologia, patrimônio e cultura material.

FN: Alguns desses argumentos foram esboçados no seu artigo de 2005, publicado na revista da EASA, Social Anthropology, como parte do dossiê sobre o futuro da antropologia. 
Naquela época eu era presidente da EASA e encontrei fundos para fazer no meu instituto uma reunião à qual chamei European Anthropological Summit. A ideia era repensar a EASA 15 anos após a sua fundação. Reunimos 50 antropólogos para debaterem as várias questões que se levantavam em torno do papel de uma antropologia europeia, e convidamos três pessoas para apresentarem papers estruturantes: Adam Kuper, Marilyn Strathern e Philippe Descola. Aliás, o resultado foi bem engraçado: Descola apresentou um ensaio sobre natureza/cultura; Kuper sobre quando a sociologia descobriu que não era antropologia nos anos 60, e Marilyn Strathern veio nos falar sobre um parque virtual de ciência em Cambridge... Quer dizer, não podia haver papers mais diferentes! Mas eu penso que até nessa polarização eles são interessantes, porque mostram esse polimorfismo da antropologia contemporânea, essa capacidade que a antropologia tem de abarcar as temáticas mais diversas, encontrando a relevância mútua entre temas na aparência totalmente distintos. Porque esta é a questão relevante - a abertura universalista da nossa disciplina continua a existir, apesar de não termos atualmente linguagem para falar dela. O meu paper chamou-se "The future of social anthropology". ${ }^{18}$

\section{CF: Título modesto... Qual era o seu ponto?}

A certa altura, decidi atacar frontalmente a questão de se havia condições para a reprodução de uma identidade disciplinar antropológica enquanto tal. É que continuo profundamente convencido de que aquilo que os antropólogos estão a fazer hoje é bom, útil e interessante. Vou aos congressos da EASA, da ASA ou da $\mathrm{ABA}$ e vejo milhares de temáticas inovadoras, interessantes, críticas, inter- ventivas, transculturais. Vejo, por exemplo, a relevância atual dos debates numa revista como a Antropology Today. Existe aí uma juventude a produzir antropologia muitíssimo interessante do ponto de vista temático, e muitíssimo relevante do ponto de vista intelectual. Mas vejo, ao mesmo tempo, a categoria "antropologia" a ruir - o que me deixa perplexo. Vejo que, nas livrarias inglesas, já não há uma seção "Antropologia"; vejo que os antropólogos (por exemplo, os franceses) têm vergonha de dizer que são antropólogos e inventam outras categorias disciplinares espúrias e passageiras; vejo que, na América, o grande público continua a achar que antropologia é uma coisa sobre "ossos" (como na série televisiva tão famosa); vejo os sociólogos teóricos a atacar a antropologia de frente - figuras como o Giddens, o Latour ou o Boaventura de Sousa Santos, que se dedicam a profetizar sobre a categoria disciplinar "antropologia," tentando redefini-la às suas luzes, como se o trabalho que os antropólogos fizeram nos últimos dois séculos não tivesse qualquer relevância atual; vejo uma enorme incapacidade de gerir o problema pós-colonial em África - os nossos colegas africanos hesitam em chamar-se antropólogos, porque identificam a antropologia com o colonialismo, coisa que é um absurdo histórico. Aliás, os antropólogos foram os principais responsáveis por desconstruir os pressupostos colonialistas e racistas inscritos nas práticas científicas modernas. Em suma, observo uma erosão da categoria "antropologia," ao mesmo tempo em que observo que aquilo que os antropólogos fazem é coisa boa e fascinante. Este, então, é o meu problema: a antropologia é coisa boa, aquilo que fazemos é útil e valioso; temos, portanto, que olhar de novo para a nossa autoimagem e revalorizá-la em novos moldes. Se eu chamei de "The future of social anthropology" o meu paper, 
é porque o Giddens tem aquele famoso texto homônimo, no qual afirma que é preciso acabar com a nossa disciplina tal como ela existe e reinventá-la segundo o que ele pessoalmente acha que deveria ser. ${ }^{19} \mathrm{E}$ eu estou a dizer: "olha só, se esse problema existe, então uma de duas: ou eu estou a ver mal, e aquilo que os nossos alunos fazem é realmente uma porcaria, ou então, se o que os nossos alunos fazem é bom, há que saber valorizar o objeto, temos que reencontrar a antropologia - não como esses teóricos da sociologia a reprofetizam a cada nova volta do moinho teórico, mas como ela realmente é, como o resultado comovente de uma história de pensamento de incrível valor humano".

CF: E é curioso pensar a identidade dos antropólogos brasileiros em relação aos cientistas políticos ou aos sociólogos. Nós estamos engajados no estudo do concreto, das microssituações, do mundo real, não com as grandes estruturas, não com o Estado, mas com aquilo que vem de baixo, portanto, nós sempre estamos à esquerda dos outros. Esta é uma imagem que eu tenho, por exemplo, da antropologia no Brasil (e que eu tenho de mim mesmo, inclusive). E é curioso que na Europa ainda seja preciso se libertar da ideia da ligação da disciplina com o colonialismo.

Este foi um dos fascínios que encontrei na antropologia brasileira: a capacidade que ela tem de, por um lado, ser um desafio intelectual e, por outro lado, ser um desafio social, de participar interventivamente na construção da sociedade. Isto tem custos intelectuais muito grandes; custos que vocês, antropólogos brasileiros, vão pagando às vezes. Mas valeu a pena; valeu a pena ir à guerra. E a prova de que valeu a pena é que realmente a antropologia brasileira está muito viva.
Eu vejo na Europa a constituição de comunidades antropológicas jovens em Portugal, na Espanha, na Áustria, na Alemanha, na Eslovênia, na Escandinávia; vejo enormes possibilidades, mas vejo ao mesmo tempo essa hesitação de que falei. Ora, essa erosão da categoria "antropologia" vem de onde? Dos Estados Unidos, da Inglaterra e da França. É aí que vocês vão encontrar um questionamento da própria sustentabilidade disciplinar da antropologia. Há razões políticas para isso. O Carlos diz que a antropologia está à esquerda - mas a esquerda e a direita desnortearam-se. A antropologia não está à esquerda, está do lado da mutualidade humana. Ora, essa vocação antropológica para a mutualidade constituiu, durante o longo período do neoliberalismo, um desafio ideológico, o que contribuiu para o sentimento de dúvida da antropologia sobre si mesma. O problema é político, mas também é teórico.

\section{FN: E como você enfrenta este problema?}

A minha intervenção foi precisamente no sentido de provocar os antropólogos das tradições hegemônicas. Foi dizer: isto prende-se a um grande problema na antropologia contemporânea, que é o "deflacionismo". Com isso eu quero mostrar uma posição cética que nega a existência de verdade. Esta atitude cética perante a própria atividade cognitiva é um mal que ataca a antropologia de uma forma especial, porque a transforma numa atividade autocentrada. Considero este um problema muito grave e tenho andado a trabalhar contra a coisa - a ver se consigo reconstituir certo realismo moderado que convenha à antropologia, quero dizer, um realismo minimalista que, não deixando de ser realismo, permita o relativismo necessário para o empre- 
endimento etnográfico, porque sem isso entramos numa espiral deflacionista a etnografia colapsa sobre si mesma. Corremos o risco de confundir a nossa herança de relativismo metodológico (o melhor que nós temos) com relativismo epistemológico (que nos tornaria irrelevantes). Creio que este problema está no fundo da dificuldade que a antropologia tem experimentado ultimamente de lidar consigo mesma. Quando figuras como o presidente da Wenner Green Foundation for Anthropological Research vêm dizer que a antropologia americana está sem rumo, quando vemos o que se está a passar, por exemplo, em termos da própria definição do que é um anthropologue na França, ${ }^{20}$ temos que compreender que este dilema não é só institucional, é também teórico. O que está em causa é a própria posição da antropologia no mundo da ciência e das humanidades. A antropologia tem que se reencontrar enquanto ciência social num mundo teórico pós-positivista. Trata-se sobretudo, creio eu, de repensar as condições de possibilidade do gesto etnográfico. Quer dizer, o gesto etnográfico não perdeu a sua produtividade, como muitos chegaram a pensar que iria acontecer com o passar da primitividade. Volto a insistir: quem são as pessoas que estão a escrever as coisas mais interessantes e criativas sobre a religião nos nossos dias - não são antropólogos? Sobre meio ambiente e sobre economia - não é na antropologia que encontramos algumas das saídas mais criativas contemporâneas? Em relação às ciências médicas e à própria prática científica, não foi da tradição antropológica que saíram as grandes pistas? A antropologia tem uma agenda muito viva e muito contemporânea - por que será que não conseguimos explicar a possibilidade teórica do gesto etnográfico? Como é possível termos chegado a um ponto em que o gesto etnográfico se tornou obscuro perante nós próprios? Eu acho que o desafio principal se situa aí.

FN: Quais são os caminhos que você enxerga para sair desse impasse, dessa contradição entre a produtividade dos antropólogos na compreensão do mundo contemporâneo e a dificuldade de se teorizar e se definir a disciplina e, especificamente, o fazer etnográfico?

Isto, na minha opinião, passa por uma crítica ao projeto sociocêntrico da modernidade. Esta crítica foi sendo realizada e, em certo sentido, foi levada a um ponto radical, sem questionar as próprias condições epistemológicas da crítica e, então, virou-se contra si própria. $\mathrm{Na}$ verdade, o que nós encontramos no presente momento são versões do paradoxo com o qual se deparou Rodney Needham nas suas obras finais. ${ }^{21}$ São versões da situação em que a antropologia leva a sua autocrítica até um ponto em que perde as condições para a explicação de si mesma, porque se radicaliza. Eu creio que, para sair desses paradoxos, é preciso um posicionamento tanto teórico quanto político. Na minha opinião, o que se passou foi que nós, ao naturalizarmos o relativismo etnográfico, ao trazermos o relativismo da metodologia para um questionamento da própria existência da possibilidade do contato com a realidade, viramos a antropologia enquanto ciência contra si mesma. Isto tem implicações epistemológicas destrutivas, mas também tem implicações práticas. Significa que, por exemplo, se a ciência é um projeto ocidental, se a antropologia é parte da ciência, então só os ocidentais é que podem fazer antropologia. Isto é ridículo - os efeitos da velha falácia do tudo-ou-nada. ${ }^{22} \mathrm{Na}$ minha opinião, esta é uma noção politicamente bem problemática, porque vem criar a possibilidade de existir um objeto que, para mim, é 
quimérico: "outras antropologias". Ora, eu não concebo tal possibilidade. Acho que, no momento em que assim pensarmos, deixaremos de ser antropólogos e passaremos a ser ideólogos. Não nego que existam sempre e necessariamente relações entre estas duas atividades, mas isto não significa que sejam uma e a mesma atividade. Esta preocupação epistêmica prende-se precisamente à necessidade que sinto de encontrar caminhos de saída para a performance deflacionista - que é uma ideational performance na medida em que realiza a transformação de um problema epistêmico em um gesto ontológico. Quer dizer, através de um truque epistêmico, eu transformo a diferença que identifico na etnografia numa diferença radical e, com isso, retiro a própria possibilidade do gesto etnográfico inicial.

FN: Esta posição teórica e política, me parece, nos permite voltar à sua trajetória.

Sim, claro, é que nunca consegui deixar de me sentir "outro" em relação às hegemonias globais que se vão sucedendo. E, ao mesmo tempo, sinto-me muito antropólogo. Vejam, quando vou a Moçambique colaborar no lançamento de uma antropologia local; quando vou a Macau dar aulas de antropologia para futuros juristas; quando venho ao Brasil dialogar convosco; quando estou em Portugal a trabalhar para a criação de uma escola de antropologia, que sentido faz eu achar que a antropologia é uma atividade "ocidental"? Como é que posso encontrar uma definição de ocidentalidade que nos abranja a nós todos? Isto para mim é um absurdo, e envolve uma posição ideológica que não me satisfaz. Eu comecei a minha vida intelectual nessa charneira entre a atividade missionária e a atividade científica e, por isso, tenho muito medo de um futuro que olhe para nós com os mesmos olhos com que nós hoje olhamos para os missionários de ontem. Eu conheci missionários que eram gente muito bem intencionada, que estava genuinamente convencida de que a missionação era a coisa melhor do mundo. Por isso, quando vejo pessoas como a Nancy Scheper-Hughes a escrever livros como Death without Weeping, ${ }^{23}$ que são formas radicais de alterização de uma sociedade, de constituição de guerras ontológicas fundacionais, recuso-me a participar, porque acho que essas pessoas estão a fazer precisamente a mesma coisa que os missionários estavam a fazer, com as mesmas "boas intenções" paternalistas. Temos de encontrar uma forma de não depender desse tipo de alterizações radicais e, precisamente, de encontrar certa atitude de reserva crítica perante nós próprios. Assim, por exemplo, quando figuras como o Max Gluckman são acusadas de serem colonialistas, eu fico furioso. O tipo vivia num mundo colonial, lá isso sim, sem dúvida. Mas quando pessoas igualmente envolvidas nas hegemonias do seu tempo chamam de colonialistas a antropólogos do passado que estavam muito mais profundamente envolvidos na crítica social do seu tempo que os que hoje os acusam, como Gluckman, acho isso um absurdo e um ato de lesa-antropologia. Da mesma maneira, acho que algumas dessas propostas de alterização radical têm raízes ideológicas tão facilmente determináveis que fico chocado pelo fato de isto não ser mais patente para toda a gente. ${ }^{24}$ Como é que nós, que somos marginais à ordem global, deixamos que algo assim passe? É realmente aí que eu creio que, por exemplo, uma antropologia feita em português (ou em espanhol, alemão ou chinês) tem um papel muito importante a cumprir. Trata-se de espaços de comunicação com alguma autonomia relativa em face das hegemonias globais, o que pode permitir alguma liberdade de negociação 
hegemônica. Eu não sou contra a existência de hegemonias, porque isso seria ser contrário à existência de sociedade... Mas sou muito a favor da sua negociação, e isto é uma coisa que vocês no Brasil fazem, e que nós antropólogos, como um todo, devemos saber maximizar como parte da nossa condição científica global.

\section{CF: Nesse panorama geral da antropologia contemporânea que estamos discutindo, e dado que você fez trabalho de campo na China, o que você poderia nos dizer sobre a antropologia feita naquele país?}

Ainda não se pode dizer que exista propriamente uma antropologia chinesa. Existe a possibilidade de vir a existir dentro de algum tempo. A violência ideológica do maoísmo foi tão profunda que não se esgota de um dia para o outro. Mesmo pessoas treinadas no estrangeiro, que hoje voltaram à China, vão demorar algum tempo para conseguir fazer esse distanciamento em relação ao nacionalismo chinês. Não é uma coisa que passe de hoje para amanhã, mas creio que acabará por ocorrer. Há uma preocupação por parte dos chineses na criação de ciências sociais; como vocês sabem, as universidades chinesas explodiram em quantidade. Há departamentos a serem fundados em Xangai, Pequim, Cantão, Kunming; é um mundo em expansão que vai eventualmente dar sinais de si, estou certo. No presente momento, contudo, a situação é difícil de apreciar, até porque os chineses continuam muito ligados a um projeto de afirmação nacional e existe um forte controle político da opinião pública. A antropologia tal como a praticamos depende muito da possibilidade de livre expressão. Na China, a violência decorrente do impacto da modernidade ainda não foi esgotada e o autoritarismo político não foi debelado. Existe ainda uma contrarreação, que tem o sentido de afirmação da China perante o mundo; o consequente nacionalismo teórico permanece muito marcado e isto dificulta o desenvolvimento da boa antropologia. Creio que é algo que demorará algum tempo a resolver-se.

CF: Você teve contatos com as universidades chinesas durante sua pesquisa em Macau?

Sim, várias vezes em Cantão mas, em 1990, fui recebido no Departamento de Sociologia da principal universidade de Pequim, a Beida; o Fei Xiaotong ${ }^{25}$ não estava presente porque já não recebia acadêmicos comuns como eu. Encontrei-me com um grupo de jovens muito interessantes, mais ou menos da minha idade, que estavam àquela altura a esforçar-se por conhecer um pouco melhor a antropologia internacional. Estavam curiosos de saber o que eu pesquisava em Macau. Expliquei-lhes o meu projeto, que era sobre euroasiáticos ${ }^{26}$ e eles pareceram achar muito interessante, embora a própria noção de "mestiço" não fosse uma coisa propriamente confortável para eles. A certa altura, comecei a dizer-lhes como gostava da antropologia que tinha sido feita sobre a China, e que estava a ler avidamente pessoas como o Freedman, ${ }_{1}^{27}$ os Potter, ${ }^{28}$ os Wolf, ${ }^{29}$ e outros. Eles contestaram: "As coisas escritas por ocidentais sobre a China nós não lemos! Não vale a pena, é uma perda de tempo. Eles não percebem nada. Agora Leach, sim, é um grande antropólogo". E passamos o resto da tarde a discutir Leach. Falamos sobretudo dos textos críticos e metodológicos do Rethinking Anthropology. ${ }^{30}$ Foi fascinante.

FN: Se a visão ocidental sobre a China era tida com desconfiança, qual era o espaço, então, para um antropólogo chinês fazer pesquisa de campo na própria China? 
Houve um colega que me disse: "Olha, você tem muita sorte. O que eu sei da antropologia é aquilo que eu não posso fazer, porque aqui, na China, nós somos obrigados a estudar minorias étnicas. Eu sou mandado em campanhas organizadas para estudar as minorias étnicas, e depois os meus relatórios são lidos por pessoas do governo, portanto, grande parte daquilo que eu escrevo é tratado como informações sobre as pessoas que eu estudo. Estou muito limitado no que posso dizer. A única vez em que eu fiz antropologia como você faz foi quando fui ao enterro do meu avô. Meu avô vinha de uma aldeia da província de Anhui. Quando ele morreu, o meu pai já falecera em Pequim, e eu era o descendente principal, portanto, a figura que lidera o luto. Então, tive que ir lá pela primeira vez na minha vida. Quando acabou o enterro, eles me deram um gabinete na secretaria da aldeia, e durante três dias as pessoas da aldeia vieram discutir comigo os problemas que tinham para eu lhes sugerir soluções e resolver disputas, porque eu era o chefe da linhagem. Durante esses três dias, aprendi tanto quanto vocês aprendem quando fazem trabalho de campo por anos". Eu achei essa história trágica e fascinante. Fato é que existe na antropologia chinesa uma enorme dificuldade de lidar com uma visão do outro sobre a China. Isto é muito forte e vai demorar algum tempo a passar.

CF: Você pode comentar sobre a antropologia em outras partes do mundo, como na Indonésia, ou no sudeste asiático?

De fato, a segunda maior comunidade antropológica fora dos EUA não está no Brasil, mas no Japão. Eles ainda estão muito orientados sobre si próprios, mesmo quando fazem etnografia no estrangeiro. Por exemplo, sobre África, fazem muita pesquisa, mas há pouco diálogo com o que se passa cá fora. O problema é que a própria categoria antropologia continua também para eles a transportar as marcas do primitivismo metodológico quando trabalham sobre o Japão, chamam-na de outra coisa, tal como na Índia chamam sociologia àquilo que, fora da Índia, passa por antropologia da sociedade hindu. No interior da Índia, só usam a expressão antropologia para se referirem ao estudo das populações não-hindus. Nós não devíamos fugir a esse desafio, fingindo que não reparamos nos efeitos perversos do primitivismo metodológico. Esta é a minha posição. Nós deveríamos confrontá-lo diretamente.

CF: Mas o que significa não fugir e confrontá-lo? É procurar uma definição ou deixá-lo suficientemente aberto para que possa abrigar todos esses diferentes modos de fazer antropologia?

Significa uma tentativa de endereçar a questão do primitivismo metodológico de uma maneira crítica e analítica. Não estou a propor autoritarismos, definições definitivas, nada disso, porque isto seria ridículo, mas debater o problema frontalmente. Veja, o Brasil tem esse mesmo problema de forma muito aguda com a separação entre etnologia e antropologia. É uma postura disciplinar que, depois, terá ecos teóricos em todas as teorizações sobre etnicidade, raça etc. Nós, na Europa, tivemos um problema semelhante com a etnologia (volkskunde) e o folclore. A SIEF (Société Internationale d'Ethnologie et de Folklore) ${ }^{31}$ continua viva; essa tradição de continuidade das etnologias de construção nacional ainda está lá. Na França, a categoria etnologia parece mesmo estar em processo de ressemantização. Contudo, no geral, o processo de integração desses debates dentro do grande campo da antropologia está a avançar a passos largos. Eu acho que temos que olhar para 
estas divisões com suspeita e esmiuçar as implicações teóricas que elas possam ter. Mais uma vez, não se trata de encontrar resoluções definitivas, porque isso não existe, mas uma tentativa de endereçar o problema.

CF: Você tem essa visão ampla de uma antropologia feita no mundo. O que você identificaria como coisas novas sendo feitas na antropologia?

Teria muita dificuldade em identificar uma coisa que fosse mais nova que as outras. A minha apreciação é que estamos a entrar num momento neoclássico, quer dizer, num período de voltar a repensar algumas das questões que marcaram a antropologia clássica e que fomos empurrando para debaixo do tapete como resultado do processo de desconstrução crítica. Por exemplo, o discurso sobre o parentesco ou sobre a ecologia estão a reemergir e de formas muitíssimo interessantes; e a reemergir em ligação direta com alguns dos debates que foram abandonados nos anos 70 . Eu creio que há muitas problemáticas do período clássico que estão a reemergir hoje, à luz precisamente da procura de certo comparativismo antropológico - o esforço por construir uma antropologia mais comparativa e mais universal. Eu vejo novas possibilidades num discurso sobre a condição humana que se prenda à própria possibilidade de fazer etnografia ao gesto etnográfico. Esta é a questão central. Por quê? Porque a antropologia hoje é uma atividade empreendida por todos os tipos de atores humanos sobre todos os tipos de atores humanos. Então, abre-se a possibilidade de voltar a uma procura dos significados da condição humana, desta vez teoricamente mais informada.

FN: O que seria um "discurso teoricamente informado sobre a condição humana"?
É por isto que me empenhei em ler Donald Davidson, ${ }^{32}$ porque ele nos ajuda a responder a algumas destas questões. O modelo que ele constrói para a possibilidade do pensamento passa pela centralidade da linguagem, mas não se limita a ela. Permite-nos compreender um bocado melhor como, sendo todos absolutamente diferentes, temos grandes áreas de sobreposição e, portanto, podemos construir sobre essas grandes áreas de sobreposição uma noção de humanidade. Não existe uma essência comum à humanidade, existem sobreposições humanas. Se a antropologia conseguir reencontrar um caminho para um comparativismo baseado num realismo minimalista e num estruturalismo mitigado, poderemos reatar com as preocupações universalistas do período clássico, agora em moldes menos eurocêntricos. Trata-se de um desafio interessante.

CF: Talvez pudéssemos concluir a conversa falando um pouco desses debates contemporâneos em relação ao que você está fazendo nesses últimos anos na Bahia.

Além de comer sarapatel... a minha vinda para o Brasil liga-se diretamente a uma triangulação com Moçambique e Macau. No princípio dos anos 2000, fui professor convidado na Universidade Eduardo Mondlane, em Maputo, numa altura em que o projeto sobre os macaenses estava a acabar e eu andava à procura de um novo projeto. Pareceu-me que o Brasil, em termos temáticos, iria responder a algumas das preocupações que tinham emergido entre Moçambique e Macau sobre as problemáticas da etnicidade e da identidade pessoal. Eu vim para aqui muito preocupado com a questão da identidade étnica. Cheguei ao Brasil e encontrei, porém, outras questões. A questão da pessoa e sua constituição afetiva tornou-se muito mais importante para mim. 
FN: Este é o foco de sua pesquisa?

Tenho estado a trabalhar sobre pessoa e nominação no Baixo Sul da Bahia. Trabalho com jovens e professores em várias escolas municipais. A temática central tem sido a forma como a emoção gera laços sociais que depois definem a pessoa no seu relacionamento com os outros. E isto veio confrontar-me com o debate sobre indivíduo/pessoa no Brasil, que teve o seu momento alto na obra de DaMatta e que necessita agora ser repensado à luz da crítica ao sociocentrismo que emergiu nos anos 90. Há hoje condições para repensar essa polarização indivíduo/pessoa na sua ligação com a ideologia eurocêntrica da modernidade e o papel que esta teve na própria constituição da sociedade brasileira. A questão levantou-se de forma inesperada para mim. Quando comecei a reunir colegas para discutir nomes de pessoa em português, sem que o tivéssemos previsto, os nossos debates acabaram por girar em torno desta questão. Os últimos textos que tenho estado a escrever são precisamente uma tentativa de reler a tradição brasileira sobre o debate pessoa/ indivíduo que se liga a uma concepção da sociedade brasileira como dilemática. ${ }^{33}$

\section{CF: O dilema brasileiro, nos termos de DaMatta.}

O dilema brasileiro: uma sociedade dividida entre uma ocidentalidade programática e uma não-ocidentalidade difusa. Por que ela é difusa? Porque ora é africana, ora é indígena, ora é portuguesa popular ou japonesa... é polifacetada. O binômio da dualidade brasileira é assimétrico. Então, essa discussão levou-me a tentar pensar o significado da alterização do Brasil perante si próprio, que se formula através, por exemplo, da imagem do demônio. A forma como o tropo demoníaco é constituinte da autoimagem do Brasil numa panóplia tão vasta de aspectos foi para mim inesperada. O próprio nome Brasil levanta logo a questão: é que a terra não deveria chamar-se assim, mas sim Terra de Santa Cruz. Já o grande João Barros (o cronista e grande engenheiro da primeira colonização) alertava para que não se chamasse a essa nova terra pelo nome do pau vermelho do "vil lucro" (o pau-brasil), mas sim pelo nome do madeiro vermelho com o sangue de Cristo. Mas perdeu a aposta! Desde esse momento fundacional até à antropofagia modernista, o tropo demoníaco é dominante nos discursos identitários brasileiros. Ele é constituído por esse movimento utópico inicial: a polarização entre o Éden e o Hades.

\section{CF: O diabo na terra de Santa Cruz...}

Precisamente! Essa polaridade é uma disjunção utópica. Por isso, a figura do Padre Antônio Vieira é tão estruturante, não é? É desse utopismo que mais tarde o projeto modernista se apropria, invertendo os polos, claro.

CF: Mas esta é uma tendência, a da interpretação dilemática, polarizante, dual; a outra é a tendência do hibridismo, do sincretismo, da mistura. Como é que essas coisas convivem?

Esse problema está a montante do Brasil e no Brasil se prolonga. Quando o Pierre Sanchis fala sobre sincretismo brasileiro, ele diz que há cá dois sincretismos: há o sincretismo europeu e o sincretismo afrobrasileiro e que, já lá na Europa, a religiosidade popular era sincrética porque o paganismo tinha sobrevivido através dos tempos. Só que a questão que nós temos que nos perguntar, honestamente, é quando é que acaba o sincretismo? Quando é que acaba o sincretismo e começa a emergir uma coisa nova? Como é que se pode afirmar-como a maior parte dos historiadores 
brasileiros e portugueses afirma - que no século XV o catolicismo em Portugal estava ainda ambiguamente instalado? Os portugueses do norte de Portugal são católicos desde cerca de 550 da Era Cristã. Nessa altura, quando São Martinho de Dume converteu a elite sueva ao catolicismo perto de Braga, eles já eram cristãos há cerca de 200 anos. Como é que se pode dizer que as formas de comportamento religioso não padronizado de hoje são sincretismo? Que paganismo é esse que vive assim imanente durante milênios? Há aqui uma espécie de polarização utópica. O objeto as práticas religiosas das pessoas - é observável e é a cada momento único, não é sincrético em si mesmo. Ele é produzido sincreticamente por quem olha para ele e o interpreta como múltiplo. Da mesma maneira, no Brasil, eu creio que há diversidades internas muito fortes, mas isto não significa que sejamos cegos às sobreposições que criam um campo que, não sendo unitário, é integrado. A própria imagem do demônio brasileiro é plural: entre um demônio Capeta sertanejo e um demônio Exu costeiro existem muitos demônios. Estes dois demônios são bem diferentes na sua constituição, mas eles existem dentro de um campo de interrelacionamento facilmente identificável. Por que é que chamamos isso de sincretismo? Por que não chamamos o cristianismo de sincretismo? Por que não chamamos o Islã de sincretismo? Afinal, a diferença de tempo não é assim tão grande, quer dizer, os portugueses já eram católicos no momento em que o Profeta escreveu o Alcorão. Estão a ver o que eu quero dizer? O sincretismo brasileiro é produzido pelo dilema brasileiro. Ora, isto tem efeitos no ideário político, mas também tem efeitos no interior da própria prática antropológica brasileira, quando aceitamos funcionar com uma disciplina que presume mundos teóricos distintos para objetos sociais diversos no interior do Brasil.

\section{Notas}

${ }^{1}$ Brancaflor: A structuralist analysis of a Portuguese folktale. 1977. Universidade de Witwatesrand. Orientador W. D. Hammond-Tooke, Examinadora Eleanor Preston-Whyte.

${ }^{2}$ Needham, Rodney. 1987. Counterpoints. Berkeley: University of California Press.

${ }^{3}$ Asger, Jorn \& Arnaud, Noël. 1968. La langue verte et la cuite: étude gastrophonique sur la marmythologie musiculinaire. Paris: Jean-Jacques Pauvert Éditeur.

${ }^{4}$ Webster, David J. 2009. A sociedade chope: Indivíduo e Aliança no Sul de Moçambique (1969-1976). Lisboa: Imprensa de Ciências Sociais.

${ }^{5}$ Habermas, Jürgen. 1971. Knowledge and human interests (Erkenntnis und Interesse). Trans. J. Shapiro. Boston: Beacon Press.

${ }^{6}$ Hammond-Tooke, W. D. 1997. Imperfect interpreters: South Africa Anthropologists. Johannesburg: Witwatersrand University Press.

${ }^{7}$ Steiner, Franz Baerman. 1999. Selected writings. J. Adler \& R. Fardon (ed.s.). Nova York: Berghahn.

${ }^{8}$ A primeira edição é de 1954 (Criterion Books, Oxford) e foi prefaciada por EvansPritchard; a segunda edição é de 1971 (University of Chicago Press).

${ }^{9}$ Cf. Pina Cabral, João de. 1989. "The Mediterranean as a category of regional comparison: a critical approach", Current Anthropology, 30(3):399-406.

${ }^{10}$ Pina Cabral, João de. 1986. Sons of Adam, Daughters of Eve: the peasant worldview of the Alto Minho (NW Portugal). Oxford: Clarendon Press (trad. port.: 1989. Lisboa: D. Quixote).

${ }^{11}$ Herzfeld, Michael. 1982. Ours once more: folklore, ideology, and the making of modern Greece. Austin: University of Texas Press. 
${ }^{12}$ Por exemplo, Strathern. Marilyn. 1984. "Subject or Object? Women and the Circulation of Valuables in Highlands New Guinea". In: Renée Hirschon (ed.). Women and Property - Women as Property. London: Croom Helm. pp. 158-175. Ou: 1982. "'Self-interest' and the social good: Some Implications of Hagen Gender Imagery". In: S. Ortner \& H. Whitehead (eds.). Sexual Meanings. Nova York: Cambridge University Press.

${ }^{13}$ Strathern, Marilyn. 1988. The gender of the gift: problems with women and problems with society in Melanesia. Berkeley: University of California Press.

${ }^{14}$ Ingold, Tim. 1996. Key debates in anthropology. London: Routledge.

${ }^{15}$ Strathern, Marilyn. 1992. After nature: English kinship in the late twentieth century. Cambridge: Cambridge University Press.

${ }^{16}$ Em terra de tufões: Dinâmicas da Etnicidade Macaense. 1993. Macau: Instituto Cultural de Macau.

17 "The Mediterranean as a category of regional comparison: a critical view", Current Anthropology, 30(3):399-406, 1989.

18 "The future of social anthropology". In: Social Anthropology, 13(2), pp. 119-128, 2005.

${ }^{19}$ Giddens, A. 1996, "The future of anthropology" In: In Defence of Sociology: Essays, Interpretations and Rejoinders. Cambridge: Polity Press. pp.121-126.

${ }^{20}$ Cabral, João de Pina. "Anthropology Challenged: Notes for a Debate". Journal of the Royal Anthropological Institute, 12(3):663-673, 2006.

${ }^{21}$ Por exemplo, Exemplars. Berkeley: University of California Press, 1985.

${ }^{22}$ Ver João de Pina Cabral. "The all-or-nothing falacy". Social Analysis (2009, no prelo).

${ }^{23}$ Scheper-Hughes, Nancy. Death without weeping: the violence of everyday life in
Brazil. Berkeley: University of California Press, 1992.

${ }^{24}$ Ver Cabral, João de Pina. "Terrorismo, suicídio e utopia: um olhar sobre o debate actual". Etnográfica, 12(2):489-500, 2008.

${ }^{25} \mathrm{O}$ famoso aluno de Malinowski, que escreveu uma das mais brilhantes etnografias sobre a China rural: Peasant Life in China. In: Chinese Village Close-Up. Beijing: New World Press, 1983 [1936].

${ }^{26}$ Cabral, João de Pina. Between China and Europe: Person, Culture and Emotion in Macao. LSE Monographs 74. London: Continuum Books/Berg, 2002.

${ }^{27}$ P.ex., Freedman, Maurice. Lineage Organization in Southeastern China. LSE Monographs 18. London: Athlone, 1980 [1958].

${ }^{28}$ P. ex., Potter, Sulamith \& Potter, Heinz. China's Peasants: The anthropology of a Revolution. New York: Cambridge University Press, 1990.

${ }^{29}$ P. ex., Wolf, Arthur \& Huang, Chieh-shan. Marriage and Adoption in China 1845-1945. Stanford: Stanford University Press, 1980.

${ }^{30}$ Leach, Edmund. Rethinking anthropology. LSE Monographs 1. London: Athlone, 1961.

${ }^{31}$ http://www.siefhome.org/

${ }^{32}$ P. ex., Davidson, Donald. Problems of Rationality. Oxford: Oxford University Press, 2004.

${ }^{33}$ Ver Cabral, João de Pina. "A pessoa e o dilema brasileiro: uma perspectiva anticesurista". Novos Estudos CEBRAP 78, pp. 95-112, 2007; "Sarakatsani reflections on the Brazilian Devil". In: Mark Mazower (ed.). Networks of Power in Modern Greece. London: Hurst \& Co., 2008. pp. 233-256; e "O Diabo e o Dilema Brasileiro: uma perspectiva anti-cesurista, II". Revista de Antropologia, 2009 (no prelo). 